\title{
First record of the blacktip reef shark Carcharhinus melanopterus (Carcharhiniformes: Carcharhinidae) from the Tropical Eastern Pacific
}

\author{
Andrés López-Garro ${ }^{1}$, Ilena Zanella ${ }^{1}$, Geiner Golfín-Duarte ${ }^{2} \&$ Maikel Pérez-Montero $^{2}$ \\ 1. Asociación Conservacionista Misión Tiburón, Playas del Coco, Guanacaste, Costa Rica; Telefax: (506) 2697-1847; \\ alopez@misiontiburon.org; izanella@misiontiburon.org \\ 2. Parque Nacional Isla del Coco. Área Conservación Marina Isla del Coco. Sistema Nacional de Áreas de Conservación, \\ Costa Rica; geiner.golfin@sinac.go.cr; elcocolaisla@hotmail.com
}

Received 19-V-2012. C Corrected 26-VI-2012. Accepted 24-IX-2012.

\begin{abstract}
The blacktip reef shark Carcharhinus melanopterus, is one of the most common Indo-Pacific reef sharks. On April 29, 2012, a juvenile male blacktip reef shark measuring $89 \mathrm{~cm}$ total length (TL), was incidentally caught during a research expedition in Chatham Bay, Isla del Coco National Park, Costa Rica, located in the Tropical Eastern Pacific. This is the first record of the species from Isla del Coco National Park, Costa Rica, and from the Tropical Eastern Pacific. Citation: López-Garro, A., I. Zanella, G. Golfín-Duarte \& M. Pérez-Montero. 2012. First record of the blacktip reef shark Carcharhinus melanopterus (Carcharhiniformes: Carcharhinidae) from the Eastern Tropical Pacific. Rev. Biol. Trop. 60 (Suppl. 3): 275-278. Epub 2012 Dec 01.
\end{abstract}

Key words: Isla del Coco National Park, Cocos Island, Carcharhinus melanopterus, blacktip reef shark, Tropical Eastern Pacific.

The blacktip reef shark, Carcharhinus melanopterus (Quoy \& Gaimard, 1824), is one of the most common Indo-Pacific reef sharks. The species is also present in the Red Sea, Western and Central Pacific, and Eastern Mediterranean (through the Suez Canal). The closest records to the Eastern Pacific are from Hawaii, Line Islands, Marquesas Islands and French Polynesia. Blacktip reef sharks inhabit shallow water coral reefs and reef flats on continental and insular shelves. They are commonly found in inshore waters but are also reported from offshore locations (Compagno 1984, 1988, Bauchot 1987, Bonfil \& Abdallah 2004, Compagno et al. 2005). C. melanopterus is viviparous and has a gestation period of 7 to 10 months. Size at birth is estimated at 33 to $50 \mathrm{~cm}$ (Compagno 1998). Sexual maturity is reached at $95 \mathrm{~cm}$ TL for males and $97 \mathrm{~cm}$ TL for females (Lyle 1987, Porcher 2005).

Blacktip reef sharks show strong site fidelity on coral reef, lagoon and sand flat habitats.
Acoustic and conventional tagging data from Palmyra Atoll, in the Western Pacific Ocean, show the species has short movements and small home ranges over a timescale of days to weeks $\left(0.55 \pm 0.24 \mathrm{~km}^{2}\right)$ (Papastamatiou et al. 2009). Stevens (1984) also reported restricted movements for the species $\left(1-3 \mathrm{~km}^{2}\right)$ in the Indian Ocean.

On April 29, 2012 at 20:00 hrs, a blacktip reef shark Carcharhinus melanopterus, was caught with hand line and a modified size 5 circular hook. Sea surface temperature at time of capture was $29.5^{\circ} \mathrm{C}$ and depth 13.4 $\mathrm{m}$. The individual was caught during a tagging expedition studying population dynamics of the whitetip reef shark Triaenodon obesus, in Chatham Bay, Isla del Coco National Park. Chatham Bay is located on the north side of Isla del Coco (Fig. 1) between coordinates $5^{\circ} 33^{\prime} 25.28^{\prime \prime} \mathrm{N}, 87^{\circ} 02^{\prime} 53.11^{\prime \prime} \mathrm{W}$ and $5^{\circ} 33^{\prime} 04.71^{\prime \prime} \mathrm{N}, 87^{\circ} 02^{\prime} 13.76^{\prime \prime} \mathrm{W}$. The bay is $1350 \mathrm{~m}$ by $610 \mathrm{~m}$ and dominated by sandy 
bottoms with scattered rocks and reefs (SibajaCordero et al. 2012), specimen was photographed, and released alive after hook removal.

Positive identification of the species was attained by analysis of the following distinctive characters (Compagno 1984, 1998, Compagno et al. 1995, 2005): (i) short rounded snout with large anterior nasal flaps (Fig. 2A), (ii) black tips on all fins, including the edge of the caudal fin's upper lobe (Figs. 2 B, C), (iii) light band that borders the black mark on the first dorsal fin (Fig. 2D), and (iv) distinctive body color: yellow-brown dorsal surface and white underside, with conspicuous dark bands on the flanks that extend back towards the pelvic fins (Fig. 2D). The shark's size $(89 \mathrm{~cm} \mathrm{TL})$ together with the low calcification of its claspers, suggests the individual was a juvenile. This is the first record of a blacktip reef shark from from Isla del Coco National Park and from the Tropical Eastern Pacific (Allen \& Robertson 1998, Bussing \& López 2005, Garrison 2005, Robertson et al. 2004, Robertson \& Allen 2008).

Garrison (2005) identified over 270 fish species (including 7 sharks and 4 rays) at Isla del Coco: 30 species have a circumtropical or circumglobal distribution and over 40 species are reported from scattered Indo-Pacific locations or throughout the Indo-Pacific Ocean (most of these are bony fish, e.g. the genus Thalassoma, that probably traveled $5000 \mathrm{~km}$ with floating debris to arrive in the Eastern Pacific Ocean). Several Indo-Pacific elasmobranchs are present at Isla del Coco, including the silvertip (Carcharhinus albimarginatus) and the white-tip shark (Triaenodon obesus). Their distribution extends into the continental waters of Central America. Other example is the marble ray (Taeniura meyeni); is only present at Isla del Coco and Galapagos Islands in the Tropical Eastern Pacific, and absent from the central american mainland (Grove \& Lavenberg 1997, Garrison 2005).

The presence of a juvenile blacktip reef shark at Isla del Coco suggests that a pregnant female traveled at least $5000 \mathrm{~km}$ and arrived at Isla del Coco to give birth at Chatham Bay. $C$. melanopterus possibly represents a new arrival for Isla del Coco National Park.

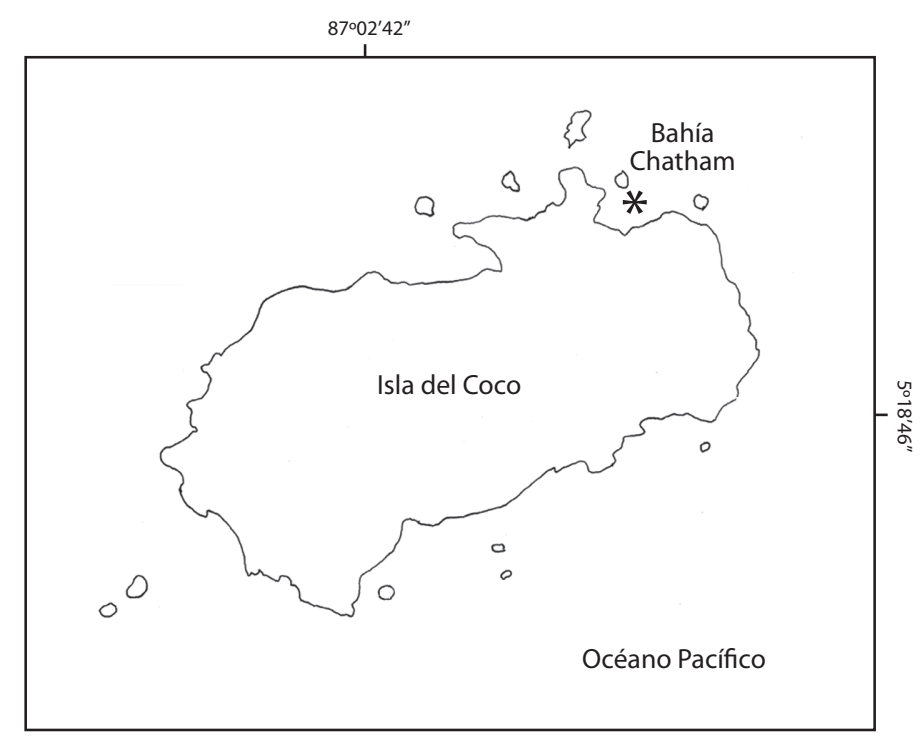

Fig. 1. Location of the first record (*) of a blacktip reef shark, Carcharhinus melanopterus, from Chatham Bay, Isla del Coco National Park, Costa Rica. 

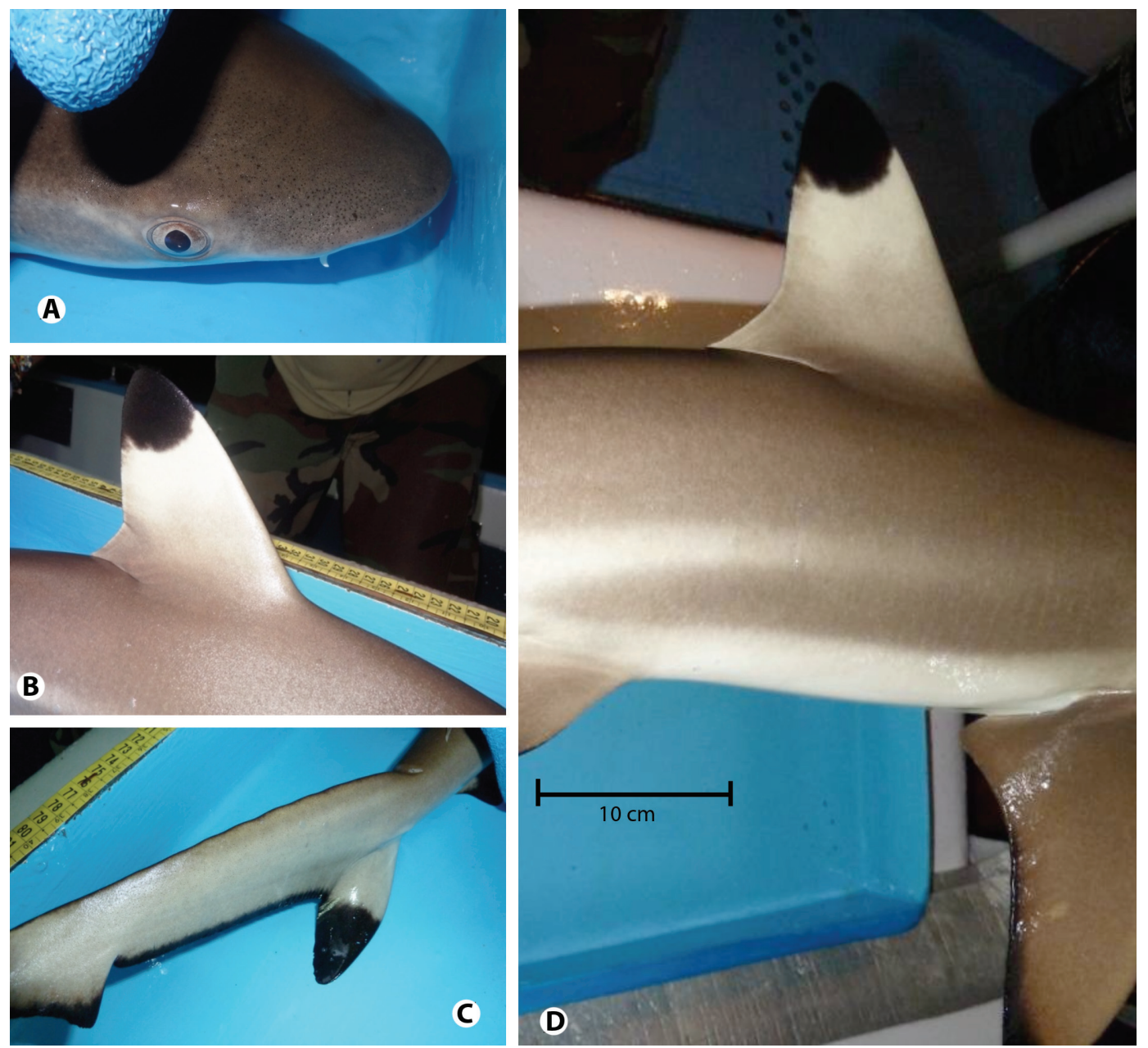

Fig. 2. Carcharhinus melanopterus captured at Chatham Bay, Isla del Coco National Park. A) Detailed is the short and rounded snout with large anterior nasal flaps. B) Image shows prominent first dorsal fin with black tip and a light band below it. C) Image shows the black edge of the upper lobe of the caudal fin. D) Body coloration of the blacktip reef shark from Chatham Bay, Isla del Coco National Park: yellow-brown on the dorsal surface and white on the ventral region, with a dark band on its flanks. Photos A-C: Carlos Hiller.

\section{ACKNOWLEDGMENTS}

We thank the personnel of Isla del Coco National Park and Isla del Coco Marine Conservation Area for their support during the research expeditions of Misión Tiburón. We are grateful to Lucy Harrison, Program Officer of IUCN Shark Specialist Group, and to the experts Dave Ebert and Gavin Naylor for confirming the identification of the species. Finally, we thank Jorge Cortés from the
University of Costa Rica and Katherine Cure from the University of Western Australia for the revision of this note.

\section{RESUMEN}

El tiburón punta negra de arrecife, Carcharhinus melanopterus, es uno de los tiburones de arrecife más comunes del Indo-Pacífico. Durante una expedición científica al Parque Nacional Isla del Coco, Costa Rica, Pacífico Tropical Oriental, un tiburón punta negra de arrecife fue capturado en Bahía Chatham, Parque Nacional Isla del 
Coco, el 29 de abril 2012. El espécimen capturado era un macho juvenil de $89 \mathrm{~cm}$. Este es el primer informe de esta especie para el Parque Nacional Isla del Coco, Costa Rica y para el Pacífico Tropical Oriental.

Palabras claves: Parque Nacional Isla del Coco, Carcharhinus melanopterus, tiburón punta negra de arrecife, Pacífico Tropical Oriental

\section{REFERENCES}

Allen, G.R. \& D. R. Robertson. 1998. Peces del Pacífico Oriental Tropical. Conabio, Agrupación Sierra Madre. Ciudad de México, México.

Bauchot M. 1987. Requins, pp. 767-843. In: W. Fischer, M. Bauchot \& M. Schneider (Eds.). Fiches FAO d'identification des espèces pour les besoins de la pêche. Méditerranée et mer Noire. Volume II. Vertébrés. FAO, Rome, Italia.

Bonfil, R. \& M. Abdallah. 2004. Field Identification Guide to the Sharks and Rays of the Red Sea and Gulf of Aden. FAO Species Identification Guide for Fishery Purposes. FAO, Rome, Italia.

Bussing, W.A. \& M.I. López. 2005. Peces de la Isla del Coco y peces arrecifales de la costa Pacífica de América Central meridional/Fishes of Cocos Island and Reef Fishes of the Pacific Coast of Lower Central America. Rev. Biol. Trop. 53 (Supl. 2): 192 p.

Compagno, L. 1984. Sharks, pp. 251-655. In W. Fischer \& G. Bianchi (Eds.). Western Indian Ocean. Volumen I-XI. FAO Species Identification Sheets for Fishery Purposes. FAO, Rome, Italia.

Compagno, L. 1998. Sharks, pp. 1193-1366. In K. Carpenter \& V.H. Niem (Eds.). The Living Marine Resources of the Western Central Pacific. Volumen II: Cephalopods, Crustaceans, Holothurians and Sharks. FAO Species Identification Guide for Fishery Purposes. FAO, Rome, Italia.
Compagno, L., F. Krupp \& W. Schneider. 1995. Tiburones, pp. 647-743. In W. Fischer, F. Krupp, W. Schneider, C. Sommer, K. Carpenter \& V. Niem (Eds.). Pacífico centro-oriental. Volumen II. Vertebrados- Parte I. Guía FAO para la identificación de especies para los fines de la pesca. FAO, Roma, Italia.

Compagno, L., M. Dando \& S. Fowler. 2005. Sharks of the World. Princeton Univ. Press, Princeton y Oxford.

Garrison, G. 2005. Peces de la Isla del Coco, 2 Edn. INBio. Santo Domingo de Heredia, Costa Rica.

Grove, J. \& R. Lavenberg. 1997. The Fishes of the Galápagos Islands. Stanford Univ. Press, Stanford, California, EUA.

Lyle, J.M. 1987. Observations on the biology of Carcharhinus cautus (Whitley), C. melanopterus (Quoy and Gaimard) and C. fitzroyensis (Whitley) from northern Australia. Aust. J. Mar. Freshwat. Res. 38: 701-710.

Papastamatiou, Y.P., C.G. Lowe, J.E. Caselle \& A.M. Friedlander. 2009. Scale-dependent effects of habitat on movements and path structure of reef sharks at a predator-dominated atoll. Ecology 90: 996-1008.

Porcher, I.F. 2005. On the gestation period of the blackfin reef shark, Carcharhinus melanopterus in waters off Moorea, French Polynesia. Mar. Biol. 146: 1207-1211.

Sibaja-Cordero, J.A., J.S. Troncoso, C. Benavides-Varela \& J. Cortés. 2012. Shallow water soft and hard bottoms of Parque Nacional Isla del Coco, Pacific Costa Rica. Rev. Biol. Trop. 60.

Robertson, D. R., J. S. Grove \& J. E. McCosker. 2004. Tropical transpacific shorefishes. Pac. Sci. 58: 507-565.

Robertson, D. R. \& G. R. Allen. 2008. Shorefishes of the tropical Eastern Pacific online information system. (April 30 ${ }^{\text {th }}$ 2012, www.stri.org/sftep).

Stevens, J.D. 1984. Life-history and ecology of sharks at Aldabra Atoll, Indian Ocean. Proc. Royal Soc. London, Biol. Sci. 222: 79-106. 